Jurnal Ners Volume 4 Nomor 2 Tahun 2020 Halaman $21-29$
JURNAL NERS
Research \& Learning in Nursing Science
http://journal.universitaspahlawan.ac.id/index.php/ners

\title{
DAMPAK COVID-19 TERHADAP TENAGA KERJA DI INDONESIA
}

\author{
Syahrial, S.Sos.I., SH., M.Si., MH \\ Universitas Pahlawan Tuanku Tambusai
}

\begin{abstract}
Abstrak
Ketenagakerjaan adalah segala sesuatu yang berhubungan dengan tenaga kerja pada waktu sebelum, selama dan setelah selesai masa hubungan kerja, baik pada pekerjaan yang menghasilkan barang maupun pekerjaan berupa. Dari aspek hukum ketenagakerjaan merupakan bidang hukum privat yang memiliki aspek publik, karena meskipun hubungan kerja dibuat berdasarkan kebebasan para pihak, namun terdapat sejumlah ketentuan yang WAJIB tunduk pada ketentuan pemerintah dalam artian hukum publik.

Dari hasil penelitian dapat disimpulkan, Pandemi juga dapat memiliki dampak ekonomi yang tidak proporsional pada segmen tertentu dari populasi, yang dapat memperburuk ketimpangan yang mempengaruhi sebagian besar kelompok pekerja, seperti : Pekerja yang sudah memiliki masalah dengan kondisi kesehatan, Kaum muda yang sudah menghadapi tingkat pengangguran dan setengah pengangguran yang lebih tinggi, Pekerja yang lebih tua yang mungkin menghadapi risiko lebih tinggi terkena masalah kesehatan yang serius dan kemungkinan menderita kerentanan ekonomi, Perempuan yang terlalu banyak mewakili pekerjaan-pekerjaan yang berada di garis depan dalam menangani pandemi dan yang akan menanggung beban yang tidak proporsional dalam tanggung jawab perawatan terkait dengan penutupan sekolah atau sistem keperawatan, Pekerja yang tidak terlindungi, termasuk pekerja mandiri, pekerja kasual dan pekerja musiman (gig workers) yang tidak memunyai akses terhadap mekanisme cuti dibayar atau sakit dan Pekerja migran yang mungkin tidak dapat mengakses tempat kerja mereka di Negara tujuan ataupun kembali pulang kepada keluarga mereka. Ketidak menentuan dan kesulitan hidup menjadikan kelompok rentan ini memerlukan jaring pengaman sosial, seperti jaminan kesehatan dan jaminan sosial. Melalui penyediaan jaminan kesehatan dan jaminan sosial, maka kehidupan masyarakat yang paling rentan menjadi terlindungi, baik pada saat tidak ada krisis maupun pada saat krisis. Dengan adanya perlindungan sosial ini, pekerja rentan dapat tetap hidup dalam kondisi sehat dan tetap mampu bekerja untuk memenuhi kehidupan mereka dan keluarganya pada hari depan. Tanpa jaminan kesehatan dan jaminan sosial, maka krisis akibat pandemi Covid-19 ini akan merenggut harapan dan kehidupan kelompok rentan.
\end{abstract}

Kata Kunci : Dampa Covid-19, Tenaga Kerja Di Indonesia

@ Jurnal Ners Prodi Sarjana Keperawatan \& Profesi Ners FIK UP 2020

$\triangle$ Corresponding author :

Address : Jl. Tuanku Tambusai No. 23 Bangkinang

Email : nersjurnal@gmail.com

Phone :0813-7118-8411 


\section{PENDAHULUAN}

Pada awal tahun 2020 sudah banyak terjadi bencana mulai dari banjir, bencana alam seperti puting beliung, tanah longsor, erupsi gunung, gelombang pasang atau abrasi, kebakaran hutan dan lahan (Karhutla) dan gempa bumi. Dan pada Maret 2020 dikejutkan dengan wabah virus corona (Covid-19) yang menginfeksi hampir seluruh negara di dunia. Dimana Covid-19 ini bermula dan terdeteksi di negara Wuhan, China pada Desember 2019 dan mulai tersebar keberbagai penjuru dunia termaksuk Indonesia pada Maret 2020. Pada awalnya virus ini diketahui pertama kali muncul di pasat hewan dan pasar seafood di kota Wuhan. Koresponden kesehatan dan sains BBC, Michelle Roberts and James Gallager mengatakan dipasar grosir hewan dan makanan laut tersebut sejumlah hewan liar seperti ular, kelelawar dan ayam, dan dari sini timbulah banyak dugaan bahwa virus ini dapat menyebar dari hewan kemanusia, dan kemudian dari manusia ke manusia. Jumlah kasus terus bertambah seiring berjalannya waktu, hingga petugas medis pun terkena infeksi virus corona. Dan pada akhirnya dikonfirmasi bahwa transmisi pheumonia ini dapat menular dari manusia ke manusia.

Sampel isolat dari pasien yang diteliti menunjukan adanya infeksi corona virus berjenis betacoronavirus tipe baru yang diberi nama pada tahun 2019 novel Coronavirus (2019-nCov). Dan pada tanggal 11 Februari 2020 World Health Organization memberi nama virus baru tersebut Severe acute respiratory syndrome coronavirus-2 (SARS-CoV-2) dan nama penyakitnya sebagai Coronavirus disease 2019 (COVID-19).

Secara global, kasus positif corona mencapai 2.601.774 kasus dengan angka kematian akibat penyakit covid-19 mencapai 183.803 jiwa, sementara pasien pasien covid-19 yang berhasil sembuh kini tercatat sebanyak 674.413 orang. Sementara di Indonesia terhitung pada tanggal 20 April 2020, sendiri total kasus positif corona telah mencapai 6.760 pasien. Semakin meningkatnya jumlah pasien yang diakibatkan Covid-19 ini membuat pemerintah Indonesia mengeluaran berbagai kebijakan untuk dapat menyelesaikan kasus Covid-19, salah satunya adalah dengan mensosialisasikan gerakan social distancing atau masyarakat menyebutnya dengan \#dirumahaja.

Hal ini dilakukan untuk dapat mengurangi bahkan memutus rantai infeksi Covid-19 dimana seseorang perlu menjaga jarak aman dengan manusia lainnya minimal 2 meter, serta tidak melakukan kontak langsung dengan orang lain. Selain itu pemerintah menerbitkan PP Nomor 21 Tahun 2020 tentang kebijakan PSBB (Pembatasan Sosial Berskala Besar) yang merupakan strategi pemerintah untuk dapat mencegah virus corona semakin menyebar, sementara itu menurut Kementrian Kesehatan (Kemenkes) RI, PSBB tak sepenuhnya membatasi seluruh kegiatan masyarakat, pembatasan tersebut hanya berlaku untuk aktivitas tertentu saja di suatu wilayah yang terduga terinfeksi Covid-19. Banyak sekolah dan Universitas yang diliburkan oleh pemerintah dengan memberlakukan belajar dan bekerja didalam rumah, membatasi kegiatan keagamaan, pembatasan moda transportasi, pembatasan kegiatan ditempat umum dan meliburkan tempat kerja dan kegiatan lainnya khusus terkait aspek pertahanan keamanan. Dengan adanya pendemi penyakit Covid-19 ini mau tidak mau beberapa perusahaan mengurangi jumlah pekerja atau karyawan sehingga terjadi PHK terhadap karyawan sebagai upaya pencegahan penyebaran penyakit. Banyak pula perusahaan yang mengambil langkah-langkah dan ektrim untuk mempertahankan bisnis mereka dan tentunya untuk mengurangi kerugian akibat covid-19. Menurut pemantauan ILO (International Labour Organization) karena adanya tindakan karantina penuh atau parsial 
saat ini sudah berdampak pada hampir 2,7 milliar pekerja, yang sudah mewakili sekitar 81 persen tenaga kerja dunia. Dalam situasi saat ini, usaha diberbagai sektor ekonomi sedang menghadapi krisis ekonomi yang dapat mengancam operasi dan kesehatan mereka, terutama di antara perusahaan kecil, sementara jutaan pekerja rentan kehilangan pekerjaan dan pendapatan serta mengalami PHK. Berdasarkan uraian di atas, maka penulis tertarik meneliti tentang "Dampak COVID-19 Terhadap Tenaga Kerja Di Indonesia”.

Berdasarkan latar belakang masalah di atas, pokok permasalahan dari penelitian ini adalah :

1. Bagaimana Dampak Covid-19 Terhadap Tenaga Kerja Di Indonesia?

2. Bagaimana Perlindungan Sosial Untuk Pekerja Rentan Covid-19 Terhadap Tenaga Kerja Di Indonesia?

\section{HASIL PENELITIAN DAN PEMBAHASAN}

1. Dampak Covid-19 Terhadap Tenaga Kerja Di Indonesia

Tenaga kerja merupakan penduduk yang berada dalam usia kerja. Menurut UndangUndang No 13 Tahun 2003 Bab I Pasal 1 ayat 2 disebutkan bahwa tenaga kerja adalah setiap orang yang mampu melakukan pekerjaan guna menghasilkan barang atau jasa baik untuk memenuhi kebutuhan sendiri maupun untuk masyarakat. Secara garis besar penduduk suatu negara dibedakan menjadi dua kelompok, yaitu tenaga kerja dan bukan tenaga kerja. Penduduk tergolong tenaga kerja jika penduduk tersebut telah memasuki usia kerja. Batas usia kerja yang berlaku di Indonesia adalah berumur 15 tahun64 tahun. Menurut pengertian ini, setiap orang yang mampu bekerja disebut sebagai tenaga kerja. Ada banyak pendapat mengenai usia dari para tenaga kerja ini, ada yang menyebutkan di atas 17 tahun ada pula yang menyebutkan di atas 20 tahun, bahkan ada yang menyebutkan di atas
7 tahun karena anak-anak jalanan sudah termasuk tenaga kerja. ${ }^{1}$

Karantina dan gangguan terhadap dunia usaha, larangan bepergian, penutupan sekolah dan langkah penutupan lainnya membawa dampak yang bersifat mendadak dan drastis terhadap pekerja dan perusahaan. Seringkali yang pertama kehilangan pekerjaan adalah mereka yang pekerjaannya sudah rentan, seperti misalnya pekerja toko, pramusaji, pekerja dapur, petugas penanganan bagasi dan petugas kebersihan. Di dunia di mana hanya satu dari lima orang yang memenuhi syarat untuk mendapatkan tunjangan pengangguran, pemutusan hubungan kerja (PHK) merupakan malapetaka bagi jutaan keluarga.

Pekerja informal, yang menyumbang sekitar 61 persen dari tenaga kerja global sangat rentan selama pandemic karena mereka harus menghadapi risiko K3 yang lebih tinggi dan kurangnya perlindungan yang memadai. Bekerja dengan tidak adanya perlindungan, seperti cuti sakit atau tunjangan pengangguran, membuat para pekerja ini mungkin perlu memilih antara kesehatan dan pendapatan, yang berisiko terhadap kesehatan mereka, kesehatan orang lain serta kesejahteraan ekonomi mereka. ${ }^{2}$

Selain pengangguran dan setengah pengangguran; krisis juga akan berdampak pada kondisi kerja, upah dan akses atas perlindungan sosial, dengan dampak negatif khususnya pada kelompok-kelompok tertentu yang lebih rentan terhadap dampak pasar kerja yang buruk. ${ }^{3}$

Pandemi juga dapat memiliki dampak ekonomi yang tidak proporsional pada segmen tertentu dari populasi, yang dapat memperburuk

1 A. Benggolo, Tenaga Kerja dan Pembangunan, Jasa Karya, Jakarta, 2017, Hlm 1

2 Salim dan Budi sutrisno, Hukum Investasi di Indonesia, Rajawali Pers, Jakarta, 2008, Hlm 21

3 Aminuddin Ilmar, Hukum Penanaman Modal Di Indonesia Cetakan Ke-4, Kencana, Jakarta, 2010, HIm 16 
ketimpangan yang mempengaruhi sebagian besar kelompok pekerja, seperti :

1. Pekerja yang sudah memiliki masalah dengan kondisi kesehatan;

2. Kaum muda yang sudah menghadapi tingkat pengangguran dan setengah pengangguran yang lebih tinggi;

3. Pekerja yang lebih tua yang mungkin menghadapi risiko lebih tinggi terkena masalah kesehatan yang serius dan kemungkinan menderita kerentanan ekonomi;

4. Perempuan yang terlalu banyak mewakili pekerjaan-pekerjaan yang berada di garis depan dalam menangani pandemi dan yang akan menanggung beban yang tidak proporsional dalam tanggung jawab perawatan terkait dengan penutupan sekolah atau sistem keperawatan;

5. Pekerja yang tidak terlindungi, termasuk pekerja mandiri, pekerja kasual dan pekerja musiman (gig workers) yang tidak memunyai akses terhadap mekanisme cuti dibayar atau sakit; dan

6. Pekerja migran yang mungkin tidak dapat mengakses tempat kerja mereka di Negara tujuan ataupun kembali pulang kepada keluarga mereka.

Pengalaman baru-baru ini dengan sindrom pernapasan akut parah (SARS), influenza A (H1N1) dan wabah virus Ebola telah menyoroti pentingnya fokus pada tempat kerja yang tidak hanya untuk mengidentifikasi populasi yang berisiko tetapi juga untuk memahami mekanisme penyebaran penyakit dan menerapkan keberhasilan langkah-langkah pengendalian dan pencegahan. Tempat kerja merupakan sarana yang efektif di mana pengusaha dan pekerja, secara bersama-sama, dapat menyebarkan informasi dan melakukan sosialiasi terkait keselamatan dan kesehatan kerja (K3), termasuk langkah-langkah pencegahan dan perlindungan untuk mengurangi penyebaran penyakit menular.
Pandemi Covid-19 memberikan dampak ganda bagi para pekerja rentan dan "kelompok rentan baru" seperti Santosa, Jayadi, dan Suniyah. ILO menyebut pekerja rentan adalah para pekerja dengan kondisi hidup tidak menentu, baik dari sisi pendapatan, jam kerja, hingga ketiadaan jaminan kesehatan dan jaminan masa tua. Para pekerja rentan ini menjadi kelompok masyarakat yang paling terpukul akibat wabah Covid-19. Mereka selama ini menggantungkan hidupnya pada pendapatan harian, sehingga menurunnya aktivitas ekonomi berpengaruh pada pendapatan dan kualitas hidup mereka.

Para pekerja rentan yang menopangkan hidup mereka pada pendapatan harian, pada kenyataannya tetap bekerja walaupun pemerintah menerapkan kebijakan physical distancing (menjaga jarak fisik). "Tidak bekerja, tidak makan" ungkap Jayadi, salah seorang pekerja mandiri, untuk menggambarkan keterpaksaannya untuk tetap bekerja demi tetap bertahan hidup. Himbauan dari pemerintah untuk mengisolasi diri selama dua minggu memang cukup efektif memutus rantai penularan virus, namun bagi pekerja rentan, hal ini berarti akan memutus sumber pendapatannya juga.

Para pekerja ini tidak hanya mengalami kerentanan dalam hal ekonomi, akan tetapi dalam hal kesehatan juga. Mereka cenderung memiliki potensi yang lebih besar untuk tertular virus corona karena tetap beraktivitas di tengah wabah yang semakin meluas. Para pengemudi ojek online, pedagang kecil, tukang becak, hingga tukang pijat, mengalami kerentanan tertular karena pekerjaan mereka menuntut untuk berinteraksi dengan banyak orang. Santoso menyadari bahaya itu, namun dia tidak punya pilihan lain selain harus tetap bekerja. "Ya pasti tau kalau itu bahaya, yang penting tetap waspada mas, soalnya kalau gak kerja, keluarga gak bisa masak" ungkapnya.

Walaupun tetap bekerja, para pekerja rentan ini mengalami penurunan pendapatan 
secara drastis dan bahkan ada yang tanpa pendapatan. Jayadi seorang penjual makanan yang mengaku setelah ada virus corona ini pendapatannya berkurang hingga 70-80\% karena pembelinya berkurang drastis. Hal senada dialami oleh Johan (25 tahun), seorang operasional Kedai Kopi di Yogyakarta mengaku mengalami penurunan pendapatan sebesar $75 \%$. "Sejak ada Covid-19, para pelanggan terutama mahasiswa pada takut keluar rumah, jadi anjlok penjualannya" sebut Johan. Menurutnya, jika kondisi seperti ini berlangsung lebih dari bulan Juni 2020, kemungkinan besar pemilik kedai kopi dapat menutup bisnisnya yang juga berakibat merumahkan para pekerjanya.

Hal serupa dialami oleh Dayat (38 tahun), pekerja mandiri yang juga membangun usaha wisata dengan warga desanya di Kulonprogo. Dengan adanya pandemi Covid-19, dia dan warga desanya harus menutup kegiatan wisata yang mereka kelola. Hal ini mengakibatkan mereka tidak bekerja sama sekali. Dengan suara yang terdengar sayu, Dayat bercerita bahwa "ada 51 pengelola, 4 warung warga, 3 penjaga bood wisata, dan 15 pemilik lahan yang sekarang gak ada pemasukannya." Dikarenakan tanpa pendapatan, maka mereka mengandalkan tabungan untuk mencukupi kebutuhan sehari-hari.

Covid-19 juga berdampak pada Setyo (47 tahun), seorang pengusaha yang memiliki bisnis agen travel wisata yang cukup besar di Yogyakarta. Sebelum adanya pandemi pendapatannya dapat mencapai 20 juta/bulan, tetapi semenjak datangnya pandemi, bisnisnya menjadi sepi, karena orang-orang menjadi takut berwisata. Akhirnya dia memutuskan untuk merumahkan seluruh pekerjanya. Namun, walaupun tidak lagi memiliki pendapatan bulanan, Setyo memiliki tabungan yang lumayan besar sehingga mampu menunjang hidupnya sehari-hari.

Berbeda dengan Setyo, Jayadi yang berjualan makanan, kebutuhan pokok hariannya dipenuhi dengan cara turut mengkonsumsi makanan jualannya. Namun, dia terpaksa harus mengambil modal usaha warungnya ketika dihadapkan dengan kebutuhan bulanan, misalnya untuk membayar listrik, air, hingga makanan hewan peliharaan. Itu karena Jadi tidak memiliki tabungan seperti halnya Setyo, karena selama ini usahanya hanya cukup untuk memenuhi kehidupan sehari-hari. Kini Jayadi tetap berjualan makanan walaupun dipenuhi dengan berbagai kekhawatiran. "Jika wabah ini gak cepat selesai, modal jualan saya bisa habis dan gak bisa jualan lagi”.

Kondisi yang lebih menyulitkan harus dialami oleh Giyem (41 tahun), perempuan paruh baya yang tinggal di pinggir Kota Yogyakarta. Sebagai pekerja mandiri yang menawarkan jasa pijat, sejak mengemukanya wabah Covid-19, dia tidak lagi mendapatkan pesanan untuk jasa pijatnya. Di tengah kondisi tersebut, apalagi dengan tanggungan sekeluarga ada empat orang, dia akhirnya memenuhi kehidupan sehari-hari dengan berhutang senilai Rp 2.000.000,- ke Dasawisma (Kelompok Ibuibu di lingkup sekitar rumah). Giyem menyebut dia berhutang karena terdesak oleh keadaan, "ya karena gak ada pemasukan mbak, karena tiap hari harus masak, jadinya ya hutang." Hal itu dilakukan karena dia tidak memiliki tabungan yang cukup untuk bertahan hidup di tengah lesunya kondisi ekonomi.

Jika Giyem harus berhutang, situasi berbeda dialami oleh Suniyah. Dikarenakan tinggal di kawasan perdesaan, Suniyah tetap bisa mencukupi kebutuhan sehar-hari tanpa harus mengambil dana dari tabungan walaupun pendapatannya menurun sampai 50\%. Suniyah bercerita bahwa di halaman rumahnya ada tanaman sayuran dan dia juga masih memiliki simpanan beras hasil panen dari sawahnya, sehingga kebutuhan sehari-hari dapat dipenuhi dengan adanya cadangan sumber daya ini.

Melihat dampak ekonomi dari pandemi Covid-19 di atas, menunjukan kepada kita 
bahwa kondisi pekerja rentan pada kenyataannya berbeda-beda. Perbedaan tempat tinggal antara desa dan kota hingga perbedaan kepemilikan properti dan jenis usaha atau pekerjaan, berbeda pula cara mereka bertahan hidup di tengahtengah krisis. Bagi pekerja rentan yang hidup di daerah perkotaan, tantangan mereka lebih berat, apalagi yang memiliki jumlah tanggungan keluarga yang banyak dan hidup di kontrakan atau kos-kosan. Selain harus berpikir bagaimana cara agar tetap bisa makan, mereka juga harus berpikir keras tentang bagaimana cara untuk membayar kos/kontrakan.

\section{Perlindungan Sosial Untuk Pekerja Rentan Covid-19 Terhadap Tenaga Kerja Di Indonesia}

Pada kenyataannya, dampak wabah Covid-19 menempatkan pekerja rentan sebagai salah satu kelompok masyarakat yang paling terdampak, walaupun ada perbedaan kondisi dan kebutuhan dari masing-masing jenis pekerjaan. Situasi tentang kapan berakhirnya wabah ini masih penuh tanda tanya besar, sehingga jika semakin lama kondisi ini berlangsung, maka akan semakin membawa pekerja rentan dalam kehidupan yang semakin tidak menentu.

Untuk mengurangi dampak yang dihadapi oleh para pekerja rentan, pemerintah dapat mengambil kebijakan dalam dua bentuk. Pertama, selama masa pandemi berlangsung; kedua, pada saat pandemi ini telah berakhir.

Pada saat pandemi Covid-19 masih berlangsung, maka hal yang paling penting untuk dipenuhi adalah kebutuhan mendasar masyarakat, yaitu kebutuhan pokok. Kebijakan stimulus dari pemerintah perlu menyasar permasalahan ini. Saat ini pemerintah telah mengeluarkan kebijakan "kartu sembako", akan tetapi tidak semua pekerja rentan mendapatkannya. Hasil penelitian kami menunjukan bahwa delapan pekerja rentan yang kami wawancara, tidak ada satupun yang mendapatkan bantuan sosial dari pemerintah.
Melalui kebijakan pemenuhan kebutuhan pokok, maka pekerja rentan tidak perlu harus berhutang dan menguras tabungannya untuk memenuhi kebutuhan hidup sehari-hari. Langkah yang dapat dilakukan pemerintah adalah mendorong pendataan secara massal para pekerja rentan dan kelompok masyarakat lain yang perlu dipenuhi kebutuhan pokoknya, melalui perluasan "kartu sembako". Kebijakan ini dapat dimulai di daerah zona merah yang merupakan episentrum penularan Covid-19 dan tempat di mana aktivitas ekonomi mengalami penurunan yang drastis.

Kedua, pasca pandemi Covid-19 ada kebutuhan dari pekerja rentan, terutama pekerja mandiri yang memiliki bidang usaha, yaitu untuk mendapatkan kredit yang terjangkau. Dengan kredit yang murah dan terjangkau, maka para pedagang kecil dapat mengaksesnya, sehingga mereka akan tetap dapat menjalankan aktivitas ekonomi pasca-wabah ini berakhir. Selain itu, bagi para pekerja rentan dan "kelompok rentan baru", mereka membutuhkan agar tetap disokong kebutuhan pokoknya sampai akhirnya situasi ekonomi menjadi normal kembali.

Belajar dari pandemi Covid-19, kita dapat melihat bahwa masyarakat, terutama kelompok rentan, membutuhkan adanya jaminan kesehatan dan jaminan sosial. Pada situasi krisis seperti akibat pandemi Covid-19 ini, kategori kelompok rentan tidak hanya pekerja mandiri, pekerja keluarga tidak dibayar, dan pekerja lepas, namun ada kelompok rentan baru, yaitu mereka yang terlempar dari pekerjaan layak. Kelompok rentan baru ini adalah para pekerja formal yang di-PHK atau dirumahkan akibat terjadinya krisis. Hal tersebut, menjadikan kondisi hidup mereka sama tidak menentunya dengan para pekerja rentan yang lain, walaupun, mereka cenderung memiliki tabungan lebih banyak atau keterampilan mumpuni dibanding pekerja rentan yang lain. 
Ketidak menentuan dan kesulitan hidup menjadikan kelompok rentan ini memerlukan jaring pengaman sosial, seperti jaminan kesehatan dan jaminan sosial. Melalui penyediaan jaminan kesehatan dan jaminan sosial, maka kehidupan masyarakat yang paling rentan menjadi terlindungi, baik pada saat tidak ada krisis maupun pada saat krisis. Dengan adanya perlindungan sosial ini, pekerja rentan dapat tetap hidup dalam kondisi sehat dan tetap mampu bekerja untuk memenuhi kehidupan mereka dan keluarganya pada hari depan. Tanpa jaminan kesehatan dan jaminan sosial, maka krisis akibat pandemi Covid-19 ini akan merenggut harapan dan kehidupan kelompok rentan.

Di negara Kondisi berkembang pada umumnya memiliki tingkat pengangguran yang jauh lebih tinggi dari angka resmi yang dikeluarkan oleh pemerintah. Hal ini terjadi karena ukuran sektor informal masih cukup besar sebagai salah satu lapangan nafkah bagi tenaga kerja tidak terdidik. Sektor informal tersebut dianggap sebagai katup pengaman bagi pengangguran. Masalah ketenagakerjaan di Indonesia sekarang ini sudah mencapai kondisi yang cukup memprihatinkan ditandai dengan jumlah penganggur dan setengah penganggur yang besar, pendapatan yang relatif rendah dan kurang merata. ${ }^{4}$ Sebaliknya pengangguran dan setengah pengangguran yang tinggi merupakan pemborosan pemborosan sumber daya dan potensi yang ada, menjadi beban keluarga dan masyarakat, sumber utama kemiskinan, dapat mendorong peningkatan keresahan sosial dan kriminal, dan dapat menghambat pembangunan dalam jangka panjang.

4 David, Kairupan, Aspek Hukum Penanaman Modal Asing Di Indonesia, Kencana, Jakarta, 2013, Hlm 13
Berikut ini beberapa masalah ketenagakerjaan di Indonesia $:^{5}$

a. Rendahnya kualitas tenaga kerja, Kualitas tenaga kerja dalam suatu negara dapat ditentukan dengan melihat tingkat pendidikan negara tersebut. Sebagian besar tenaga kerja di Indonesia, tingkat pendidikannya masih rendah. Hal ini menyebabkan penguasaan ilmu pengetahuan dan teknologi menjadi rendah. Minimnya penguasaan ilmu pengetahuan dan teknologi menyebabkan rendahnya produktivitas tenaga kerja, sehingga hal ini akan berpengaruh terhadap rendahnya kualitas hasil produksi barang dan jasa.

b. Jumlah angkatan kerja yang tidak sebanding dengan kesempatan kerja, Meningkatnya jumlah angkatan kerja yang tidak diimbangi oleh perluasan lapangan kerja akan membawa beban tersendiri bagi perekonomian. Angkatan kerja yang tidak tertampung dalam lapangan kerja akan menyebabkan pengangguran. Padahal harapan pemerintah, semakin banyaknya jumlah angkatan kerja bisa menjadi pendorong pembangunan ekonomi.

c. Persebaran tenaga kerja yang tidak merata, Sebagian besar tenaga kerja di Indonesia berada di Pulau Jawa. Sementara di daerah lain masih kekurangan tenaga kerja, terutama untuk sektor pertanian, perkebunan, dan kehutanan. Dengan demikian di Pulau Jawa banyak terjadi pengangguran, sementara di daerah lain masih banyak sumber daya alam yang belum dikelola secara maksimal.

d. Pengangguran, Terjadinya krisis ekonomi di Indonesia banyak mengakibatkan industri di Indonesia mengalami gulung

5 Ana Rokhmatussa'dyah, Hukum Investasi Dan Pasar Modal cet-2, Sinar grafika, Jakarta, 2010, HIm 39 
tikar. Akibatnya, banyak pula tenaga kerja yang berhenti bekerja. Selain itu, banyaknya perusahaan yang gulung tikar mengakibatkan semakin sempitnya lapangan kerja yang ada. Di sisi lain jumlah angkatan kerja terus meningkat. Dengan demikian pengangguran akan semakin banyak.

e. Problem Gaji/UMR, Salah satu problem yang langsung menyentuh kaum buruh adalah rendahnya atau tidak sesuainya pendapatan (gaji) yang diperoleh dengan tuntutan untuk memenuhi kebutuhan hidupnya beserta tanggungannya. Faktor ini, yakni kebutuhan hidup semakin meningkat, sementara gaji yang diterima relatif tetap, menjadi salah satu pendorong gerak protes kaum buruh. Adapun dalam sistem ekonomi Kapitalis, rendahnya gaji buruh justru menjadi penarik bagi para investor asing. Termasuk pemerintah, untuk kepentingan peningkatan pendapatan pemerintah (bukan rakyat), justru memelihara kondisi seperti ini. Kondisi ini menyebabkan pihak pemerintah lebih sering memihak 'sang investor', dibanding dengan buruh (yang merupakan rakyatnya sendiri) ketika terjadi krisis perburuhan. Rendahnya gaji juga berhubungan dengan rendahnya kualitas SDM. Persoalannya bagaimana, SDM bisa meningkat kalau biaya pendidikan mahal. Solusi terhadap problem UMR dan UMD ini tentu saja harus terus diupayakan dan diharapkan mampu membangun kondisi seideal mungkin.

Maka dari pada itu, pengusaha dan organisasi mereka harus mematuhi saran yang diberikan oleh otoritas nasional dan lokal, termasuk terkait pengaturan kerja dan mengomunikasikan informasi penting kepada pekerja. Mereka harus menilai potensi risiko gangguan terhadap usaha, meninjau atau menyusun rencana kesinambungan usaha yang konsisten dengan pedoman yang diberikan oleh otoritas nasional dan lokal demi meningkatkan ketahanan usaha dan mendukung pekerja dan keluarga mereka. Pengusaha harus mengidentifikasi dan mengurangi risiko terhadap pekerja dan orang lain terkait dengan tempat kerja yang diakibatkan oleh wabah dan mempromosikan kebersihan di tempat kerja. Mereka juga harus menilai tanggung jawab perusahaan untuk kompensasi pekerja, khususnya di sektor-sektor berisiko tinggi, serta mencari saran dan dukungan dari pengusaha dan organisasi keanggotaan bisnis yang dapat menyalurkan keprihatinan kepada pemerintah dan membentuk langkah-langkah kebijakan yang kondusif untuk ketahanan dan keberlanjutan usaha.

\section{KESIMPULAN}

Berdasarkan uraian diatas, maka penarikan kesimpulannya adalah sebagai berikut :

1. Pandemi juga dapat memiliki dampak ekonomi yang tidak proporsional pada segmen tertentu dari populasi, yang dapat memperburuk ketimpangan yang mempengaruhi sebagian besar kelompok pekerja, seperti : Pekerja yang sudah memiliki masalah dengan kondisi kesehatan, Kaum muda yang sudah menghadapi tingkat pengangguran dan setengah pengangguran yang lebih tinggi, Pekerja yang lebih tua yang mungkin menghadapi risiko lebih tinggi terkena masalah kesehatan yang serius dan kemungkinan menderita kerentanan ekonomi, Perempuan yang terlalu banyak mewakili pekerjaan-pekerjaan yang berada di garis depan dalam menangani pandemi dan yang akan menanggung beban yang tidak proporsional dalam tanggung jawab perawatan terkait dengan penutupan sekolah atau sistem keperawatan, Pekerja yang tidak terlindungi, termasuk pekerja mandiri, pekerja kasual dan pekerja 
musiman (gig workers) yang tidak memunyai akses terhadap mekanisme cuti dibayar atau sakit dan Pekerja migran yang mungkin tidak dapat mengakses tempat kerja mereka di Negara tujuan ataupun kembali pulang kepada keluarga mereka.

2. Ketidak menentuan dan kesulitan hidup menjadikan kelompok rentan ini memerlukan jaring pengaman sosial, seperti jaminan kesehatan dan jaminan sosial. Melalui penyediaan jaminan kesehatan dan jaminan sosial, maka kehidupan masyarakat yang paling rentan menjadi terlindungi, baik pada saat tidak ada krisis maupun pada saat krisis. Dengan adanya perlindungan sosial ini, pekerja rentan dapat tetap hidup dalam kondisi sehat dan tetap mampu bekerja untuk memenuhi kehidupan mereka dan keluarganya pada hari depan. Tanpa jaminan kesehatan dan jaminan sosial, maka krisis akibat pandemi Covid-19 ini akan merenggut harapan dan kehidupan kelompok rentan.

\section{SARAN}

Berdasarkan kesimpulan diatas, maka saran yang dapat penulis berikan adalah sebagai berikut :

1. Untuk pengusaha dan organisasi, mereka harus mematuhi saran yang diberikan oleh otoritas nasional dan lokal, termasuk terkait pengaturan kerja dan mengomunikasikan informasi penting kepada pekerja. Mereka harus menilai potensi risiko gangguan terhadap usaha, meninjau atau menyusun rencana kesinambungan usaha yang konsisten dengan pedoman yang diberikan oleh otoritas nasional dan lokal demi meningkatkan ketahanan usaha dan mendukung pekerja dan keluarga mereka. Pengusaha harus mengidentifikasi dan mengurangi risiko terhadap pekerja dan orang lain terkait dengan tempat kerja yang diakibatkan oleh wabah dan mempromosikan kebersihan di tempat kerja. Mereka juga harus menilai tanggung jawab perusahaan untuk kompensasi pekerja, khususnya di sektor-sektor berisiko tinggi, serta mencari saran dan dukungan dari pengusaha dan organisasi keanggotaan bisnis yang dapat menyalurkan keprihatinan kepada pemerintah dan membentuk langkah langkah kebijakan yang kondusif untuk ketahanan dan keberlanjutan usaha.

2. Untuk pekerja dan organisasi mereka juga harus memainkan peran penting untuk berpartisipasi dalam pengambilan keputusan dan respons kebijakan terhadap epidemi. Di tingkat tempat kerja, pekerja dan perwakilan mereka harus secara aktif bekerja sama dengan pengusaha dalam pelaksanaan tindakan pencegahan dan perlindungan. Mereka harus secara ketat mengikuti praktik higienitas di tempat kerja dan mengadopsi perilaku yang bertanggung jawab. Organisasi pekerja harus berkontribusi pada pencegahan dan perlindungan pekerja dengan memberikan informasi terbaru. Mereka harus mempromosikan solidaritas dan non-diskriminasi terhadap pekerja dan orang yang sakit.

\section{DAFTAR PUSTAKA}

A. Benggolo, Tenaga Kerja dan Pembangunan, Jasa Karya, Jakarta, 2017

Aminuddin Ilmar, Hukum Penanaman Modal Di Indonesia Cetakan Ke-4, Kencana, Jakarta, 2010

Ana Rokhmatussa'dyah, Hukum Investasi Dan Pasar Modal cet-2, Sinar grafika, Jakarta, 2010

David, Kairupan, Aspek Hukum Penanaman Modal Asing Di Indonesia, Kencana, Jakarta, 2013

Salim dan Budi sutrisno, Hukum Investasi di Indonesia, Rajawali Pers, Jakarta, 2008 